\title{
Retskrivningsordbog mellem to stole
}

\begin{abstract}
In November 2012, the fourth edition of the official Danish orthographic dictionary, Retskrivningsordbogen, was published by the Danish Language Board which, according to national law, is authorised to establish the official Danish orthography and publish its decisions in the form of a dictionary, now available in both a printed and an electronic version. In order to be high quality, a work of this sort requires knowledge of language policy and linguistics, on the one hand, and lexicography, on the other hand. The article analyses the Retskrivningsordbogen exclusively from the point of view of lexicographic theory and practice, based upon a similar analysis of the previous edition (cf. Tarp 2002). It registers a number of improvements but also some stagnation and new problems in other aspects. The general conclusion is that the Danish Language Board could benefit from lexicographic knowhow as well as the new information technologies, especially with a view to developing the electronic version which should no longer be conceived as a copy of its printed counterpart but as a user-friendly extension with more lemmata and additional data.
\end{abstract}

\section{Indledning}

Den 9. november 2012 udkom fjerde udgave af den officielle danske Retskrivningsordbog, både i elektronisk og printet udgave. Blandt de hundrede tusinder af ordbøger, som gennem tiderne er blevet publiceret på det ene eller andet medie, har Retskrivningsordbogen en særstatus. Den er ikke som udgangspunkt et resultat af et forlags eller nogle forfatteres egen beslutning og "frie vilje". Den er tværtimod en bunden opgave, som har sit ophav i to love vedtaget af det danske Folketing, nemlig Lov om dansk retskrivning (Lov 320) og Lov om Dansk Sprogncevn (Lov 332), begge af 14. maj 1997. I førstnævnte står der entydigt i paragraf 1, at "Dansk retskrivning fastlægges af Dansk Sprognævn og offentliggøres i Dansk Sprognævns retskrivningsordbog”. Og i sidstnævnte skitseres blandt andet de principper, som Dansk Sprognævn skal lade sig vejlede af ved fastlæggelsen af dansk retskrivning. Disse principper er yderligere uddybet i Bekendtgørelse om Dansk Sprognavns virksomhed og sammensœetning fra 2009.

Så langt så godt!

Den nye udgave af Retskrivningsordbogen har som sædvanlig sat gemytterne i kog. Og godt for det. Det er vores alle sammens modersmål, der er på spil. Nogle er utilfredse med de ca. 1750 ændringer af den officielt tilladte retskrivning, som er foretaget siden tredje udgave (2001). Andre mener ikke, at der er foretaget ændringer nok. Og atter andre gør troskyldigt honnør og forsøger at indordne sig med en grimasse, der kan passe.

En central og relevant del af den fremsatte kritik kan læses i en række indlæg af Henning Bergenholtz (2012a-g, 2013a-b).

Denne artikel vil i den udstrækning, det er muligt, ikke blande sig i ovenstående diskussion, selv om forfatteren selvsagt har sin mening om mange af de ændringer og ikke-ændringer, der er foretaget. Årsagen til denne påtagede tavshed er hverken opportunisme eller overdreven autoritetstro, men den kendsgerning, at det danske Folketing har givet Dansk Sprognævn to forskellige

\footnotetext{
* Sven Tarp

Center for Leksikografi

Aarhus Universitet

School of Business and Social Sciences

Jens Chr. Skous Vej 4

DK-8000 Aarhus $C$

st@asb.dk
} 
hatte, som kan beundres eller kritiseres hver for sig, selv om de i sidste ende går op i en højere enhed i ét og samme produkt.

Folketinget har på den ene side bemyndiget Sprognævnet til at fastlægge den danske retskrivning, som ifølge loven skal overholdes af alle i offentlige stillinger (og helst også af alle andre). Denne del af opgaven er en sprogpolitisk opgave, som nødvendigvis må løses ud fra lingvistiske og andre principper, ikke mindst dem der er nævnt i Dansk Sprognævns eget lovgrundlag. Men i sin vished - eller måske mangel på samme - har det danske Folketing samtidig pålagt Sprognævnet at offentliggøre sine retskrivningsmæssige beslutninger i form af en officiel ordbog, Retskrivningsordbogen. Denne del af opgaven er en leksikografisk opgave, hvis løsning kræver helt andre (leksikografiske) principper, navnlig hvis løsningen skal være optimal eller blot tilfredsstillende (om forholdet mellem sprogpolitik og leksikografi henvises til Bergenholtz \& Gouws 2006 og Gouws \& Tarp 2008).

Det er en dristig beslutning af det danske Folketing. Spørgsmålet er nemlig, om Dansk Sprognævn er klædt tilstrækkeligt godt på til at klare begge opgaver med den ønskede kvalitet. Det kan næppe undre, at stort set hele den offentlige debat om den nye ordbog har drejet sig om den sprogpolitiske side af opgaven. Det er straks mere bekymrende, at det samme også gør sig gældende i de publikationer, som Sprognævnets medarbejdere selv har forfattet i denne anledning. Det gælder for eksempel de elleve artikler i Nyt fra Sprognaevnet nr. 1, 2013, som udelukkende er dedikeret til den nye ordbog. Den leksikografiske vinkel synes ikke at have fået den fornødne opmærksomhed, selv om den er en absolut forudsætning for, at det endelige produkt kan leve op til informationssamfundets behov og kvalitetskrav.

Denne artikel vil derfor udelukkende kigge på den leksikografiske side af sagen og vil kun i det omfang, hvor det er absolut nødvendigt, inddrage sprogpolitiske aspekter. Artiklen er en opfølgning på en tilsvarende artikel om Retskrivningsordbogens tredje udgave (se Tarp 2002).

\section{To hovedfunktioner og mange underfunktioner}

Baggrunden for Folketingets opdrag til Sprognævnet er, at der i samfundet findes en række behov for meget specifikke informationer om, hvordan det danske sprog skal skrives. Ifølge den leksikografiske funktionsteori er de informationsbehov, som potentielle brugere af ordbøger kan have, bestemt dels af disse brugeres leksikografisk relevante karakteristika og dels af den sociale kontekst eller situation, hvor behovene kan opstå (se Tarp 2008).

Brugergruppen er både let og svær at indkredse. Overordnet set består den af alle dansktalende - etniske danskere såvel som udlændinge - der ønsker eller har behov for at skrive tekster på korrekt dansk. Det er en uhyre bred og heterogen gruppe, der selvsagt - trods det fælles behov for informationer om korrekt skriftsprog - har forskellige slags behov, når de konsulterer Retskrivningsordbogen med henblik på at trække de relevante informationer ud af dens mange leksikografiske data. I en trykt ordbog kan det være vanskeligt at tage hensyn til alle disse forskelligartede behov, eftersom den nødvendigvis må finde en løsning, der balancerer mellem to ekstremer, nemlig forstyrrende dataoverlæs til nogle brugere på den ene side og manglende eller utilstrækkelige data til andre brugere på den anden side. En nuanceret servicering af de enkelte brugertypers behov er imidlertid noget, som med fordel kan løses i en netudgave. Men det kræver specifik leksikografisk teori, metode og teknik.

Med hensyn til de kontekster, hvor behovet for informationer om retskrivning kan opstå, er de grundlæggende set af to slags: kommunikative og kognitive. I forbindelse med førstnævnte er der mindst fire kommunikative situationer, hvor en retskrivningsordbog kan yde hjælp, nemlig ved skrivning, sprogrevision, korrekturlæsning og retning af opgaver. Det interessante er her, at i de tre sidste tilfælde står den, der har brug for informationer om retskrivning, over for en allerede eksisterende skriftlig tekst, der kan være rigtig eller forkert i forhold til Sprognævnets retskrivningsregler. Dette stiller særlige krav til ordbogskonceptet og forberedelsen af de tilgangsveje herunder søgemekanismer - som ordbogen tilbyder sine brugere. 
Ud over den evidente kommunikative grundfunktion har Retskrivningsordbogen også en kognitiv funktion i forhold til en mindre, men absolut betydningsfuld del af den samlede brugergruppe. Det drejer sig om de personer, som i kraft af deres stilling - eller bare af nysgerrighed - har behov for et samlet overblik over de ændringer, som er sket af retskrivningen siden ordbogens tredje udgave fra 2001. Det gælder blandt andet undervisere, korrekturlæsere, oversættere og andre professionelle sprogfolk, der selvsagt ikke har tid til at slå hvert eneste ord op for at finde ud af, om dets stavemåde eller bøjningsmønster er blevet ændret. Sådanne brugere har behov for en let tilgangelig liste over alle ændringer, hvor de hurtigt kan orientere sig uafhængigt af en konkret retskrivningssituation.

\section{Beskrivelse af Retskrivningsordbogen}

Den trykte udgave af Retskrivningsordbogen indeholder fire hoveddele, nemlig forord, brugsvejledning ( 12 sider), den egentlige ordbog ( 870 sider) og en 164 -sider oversigt over dansk retskrivning indbefattet register. Hertil kommer en oversigt over anvendte forkortelser og ordforklaringer, klogeligt anbragt såvel først som sidst i ordbogen.

Den elektroniske udgave er straks sværere at beskrive, eftersom den er integreret i Dansk Sprognævns generelle webside, der også indeholder links til sider uden direkte tilknytning til ordbogen. Med lidt god vilje kan man sige, at den indeholder en kort beskrivelse af ordbogens indhold, en oversigt over de vigtigste ændringer siden 2001-udgaven, tre lister over ændrede stave-, ord- og bøjningsformer, en redegørelse for ændringer godkendt af de relevante ministre, uddybende læsning (henvisning til en række artikler i tidskriftet Nyt fra Dansk Sprogncevn) samt selve søgefunktionen i ordbogen. Dertil kommer links til retskrivningsreglerne, oversigt over redaktionens medlemmer, distribution, retskrivningens historie og historien bag ændringerne. Det generelle indtryk er, at Retskrivningsordbogens netudgave fører en noget anonym tilværelse blandt mange andre vigtige informationer fra Sprognævnet og dermed fremtræder ufokuseret som leksikografisk redskab.

Når man sammenligner de to udgaver, er det første, der springer i øjnene, en række væsentlige indholdsmæssige forskelle. Nogle af disse forskelle kan forklares ud fra det pågældende medies karakter, mens andre virker nærmest uforståelige. Det er således klart, at den trykte udgave på i alt 1056 sider dårligt kan tåle at blive ret meget større, hvis den stadig skal være håndterbar for brugerne. Det er derfor naturligt, at en række oplysninger udelukkende er at finde i netudgaven, hvor lagerkapaciteten teoretisk set er ubegrænset.

Eksempelvis indeholder den trykte ordbog ikke en oversigt over de ca. 1750 ændringer af stave-, ord- og bøjningsformer, der er foretaget siden sidste udgave af Retskrivningsordbogen. Dette forekommer ikke urimeligt, da en sådan oversigt ville have betydet et større antal ekstra sider. Det kan dog undre, at papirudgaven end ikke giver en henvisning til de tre lister over foretagne ændringer, som kan tilgås via websiden. Disse lister opfylder de vigtige kognitive behov, som er nævnt ovenfor, og de var også en af de mangler, som blev påpeget af Tarp (2002: 203). Der vil stadig være brugere af den trykte ordbog med disse behov, og det kan ikke forventes, at de af sig selv finder ud af, at deres behov kan dækkes i online-versionen. En enkelt henvisning - for eksempel i forordet - kunne have været tilstrækkelig. En endnu bedre løsning ville dog være også at medtage den 7-punkts Oversigt over de vigtigste cendringer, som findes på nettet, og som fylder under en trykt side.

En anden uforståelig leksikografisk beslutning er, at hverken den brugsvejledning eller den oversigt over anvendte forkortelser og ordforklaringer, som findes i den trykte ordbog, er medtaget $\mathrm{i}$ webversionen - og det på trods af at artiklerne her er opbygget efter helt samme læst som i papirudgaven. Dette virker som en åbenbar inkonsekvens, ikke mindst fordi lagerkapaciteten ikke lægger nogen begrænsninger i denne henseende. Hvis man mener, at sådanne hjælpetekster er nødvendige i den ene udgave, er de det vel også i den anden udgave, så længe de enkelte artikler er identiske. 


\section{Forbedringer siden sidste udgave}

Tarp (2002) fremsatte ti konkrete leksikografiske kritikpunkter af Retskrivningsordbogens tredje udgave. Stilles disse kritikpunkter op imod den nye udgave, kan der iagttages en række klare forbedringer, men desværre også stagnation og videreførelse af gamle problemer. Vi starter her med positivlisten.

Blandt forbedringerne kan nævnes den allerede omtalte oversigt over cendrede stave-, ord- og bøjningsformer (punkt 5). Denne oversigt er givet i form af tre separate lister med forskellige typer af ændringer. Det er i og for sig ganske udmærket, men man kunne måske også have ønsket en samlet fyldestgørende liste med alle ændringer. Der er ingen pladsmæssige hindringer for en sådan løsning, som kunne give de interesserede brugere mulighed for at tilgå ændringerne ad forskellige veje alt efter deres specifikke behov.

En anden klar forbedring er, at fjerde udgave konsekvent anfører orddeling ved alle ord (punkt 9). Selv om Retskrivningsordbogen også denne gang forklarer de almene regler for orddeling i den separate oversigt over retskrivningsregler, er den specifikke angivelse af orddeling i selve ordlisten en stor hjælp for mange brugere, herunder korrekturlæsere, som dagligt står over for dette problem.

Tarp (2002) påpegede også en række tilfælde, hvor den daværende udgave ikke var "specielt brugervenlig over for folk, der ikke er vant til at slå op i ordbøger" (punkt 8). Et eksempel på dette var mange datidsendelser af udsagnsord, hvor brugeren selv skulle gætte, at e'et fra infinitivformen skal udelades:

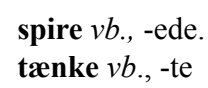

Eksempel 1. To artikler fra Retskrivningsordbogens 2001-udgave

Dette problem var godt nok forklaret i ordbogens brugervejledning, men man kan desværre ikke forvente, at denne vil blive brugt efter hensigten. Sprognævnet har taget kritikken til selv og har i den nye udgave fundet følgende løsning, hvor e'et i det ene tilfælde er udeladt (spire), mens problemet i det andet tilfælde er løst ved at skrive det stærkt bøjede toenke i sin fuldform i datid og tillægsform:

spi|re $v b .,-r,-d e,-t$; frøene spirer; et spirende venskab

tæn|ke $v b .,-r$, tænkte, tænkt

Eksempel 2. To artikler fra Retskrivningsordbogens 2012-udgave

Et andet knap så brugervenligt princip i 2001-udgaven var, at den kun anførte bestemt flertalsform af navneord, når denne var uregelmæssig. Det blev gjort ved hjælp af den metaleksikografiske forkortelse $b f . p l$., som den urutinerede og lingvistisk uskolede bruger kan have meget svært ved at tyde:

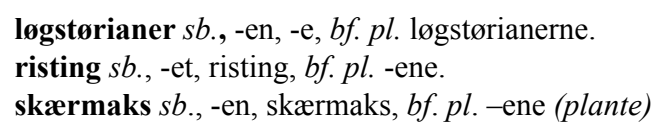

Eksempel 3. Tre artikler fra Retskrivningsordbogens 2001-udgave

Sprognævnet har også i dette tilfælde taget kritikken til selv og valgt en mere brugervenlig løsning:

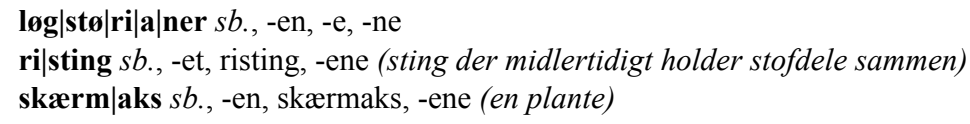

Eksempel 4. Tre artikler fra Retskrivningsordbogens 2012-udgave 
Den nye løsning er langt bedre og mere brugervenlig, selv om en angivelse af bøjningsformerne i deres fulde form ville være det optimale. En sådan løsning ville selvsagt tage meget plads op i den trykte udgave, mens den i den elektroniske ville være uproblematisk. Men Sprognævnet har fastholdt det princip, at ordbogsartiklerne i de to udgaver skal være identiske, ikke kun i indholdet men også i formen. Vi vil senere diskutere, om dette er en fornuftig beslutning.

I denne forbindelse skal det også nævnes, at den nye udgave af Retskrivningsordbogen nu altid - ifølge brugsvejledningen - giver "oplysning om bestemt form singularis, ubestemt form pluralis og bestemt form pluralis når disse kendes”. Dette repræsenterer også en klar leksikografisk forbedring i retning af mere optimal brugerservice. Desværre må man i flere tilfælde konstatere, at Sprognævnet tilsyneladende ikke altid kender de pluralisformer, som faktisk findes og bruges. Det gælder for eksempel DNA, hvor flertalsformerne DNA'er og DNA'erne ikke er anført, selv om de - omend knap så hyppigt - faktisk bruges, sådan som det blandt andet er afspejlet i Den Danske Netordbog:

DNA forkortelse <et; DNA'et, DNA'er, DNA'erne>

Eksempel 5. Uddrag af artikel fra Den Danske Netordbog

I sin kritik af lemmabestanden i Retskrivningsordbogens tredje udgave påpegede Tarp (2002) også en række åbenbare undladelsessynder, som vidnede om en usystematisk selektionsproces (punkt 2):

Man har medtaget totifem, tretifem, firtifem, sekstifem, syvtifem, ottifem og nitifem, men ikke femtifem. Man har opslagsordene enåring, toåring, treåring, fir(e)åring og seksåring, men ikke femåring. Man finder endvidere nordud hhv. nordude, vestud hhv. vestude og østud hhv. østude, men ikke sydud og sydude. Og endelig er det kun borgerne i Frederiksborg Amt og Storstrøms Amt, der kan få hjælp til at stave til deres amt, mens borgerne i landets øvrige 12 amter ikke får denne hjælp. (Tarp 2002: 202)

Den nye udgave af Retskrivningsordbogen har kun delvis taget hensyn til denne kritik. Femtifem og femårig er nu begge optaget som lemmata, mens Frederiksborg Amt og Storstrøms Amt helt er slettet, så der også på det punkt er kommet mere systematik i tingene. Men af uransagelige årsager leder man stadig forgæves efter sydud og sydude! På samme måde har ordbogen lemmatiseret både deskriptiv og deskription, men kun prceskriptiv og ikke prceskription, der ellers er ret så relevant for den retskrivningsmæssige opgave, som Sprognævnet har fået af det danske Folketing. Som et plaster på såret er Sprognævnet dog blevet mere konsekvent, når det drejer sig om at anføre betegnelsen for indbyggere i de lande, som er lemmatiseret i ordbogen. Det gælder eksempelvis senegaleser, som ikke figurerede i sidste udgave, selv om Senegal var anført som lemma. Men generelt set er der stadig et stykke vej til den systematik, som man kunne forvente af en officiel retskrivningsordbog.

\section{Fortsatte problemer i præsentationen af verber}

Tarp (2002) påviste flere tilfælde, hvor artiklerne i den daværende udgave af Retskrivningsordbogen var inkonsekvent opbygget (punkt 10). Det gjaldt eksempelvis præsentationen af udsagnsord, hvor der på den ene side var ord som hente, låne og mire, der ud over den lemmatiserede infinitivform kun havde tilordnet datidsformen, og på den anden side ord som spå, så og misforstå, der blev præsenteret med nutids-, datids-, tillægs- og lideform (i nutid):

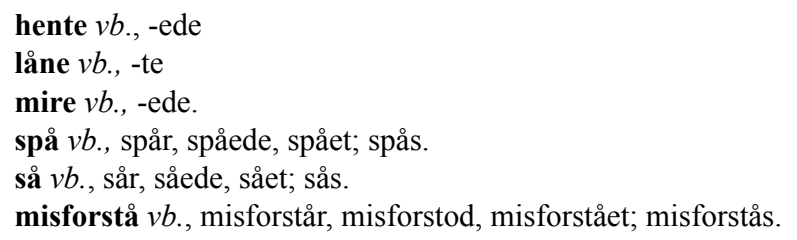

Eksempel 6. Seks artikler fra Retskrivningsordbogens 2001-udgave 
I den nye udgave har Sprognævnet valgt konsekvent at anføre nutids-, datids- og tillægsform for alle verber, mens verber der ikke ender på tryksvagt $-e$, også har tilordnet lideformen (mire er i mellemtiden gledet ud af ordbogen):

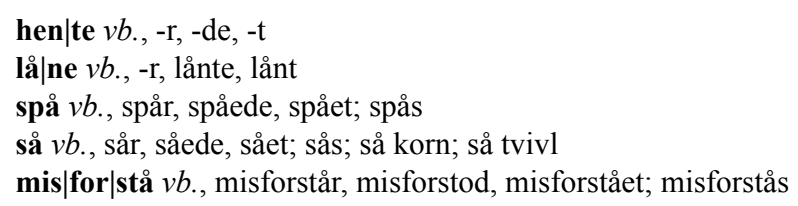

Eksempel 7. Fem artikler fra Retskrivningsordbogens 2012-udgave

Dette repræsenterer endnu en forbedring, hvor Sprognævnet har lyttet til kritikken. At lideformen kun medtages for verber, der ikke ender på tryksvagt -e, kan sagtens forsvares, selv om en konsekvent angivelse af denne form måske ville have været endnu bedre (og pladsslugende) med henblik på den svageste del af den potentielle brugergruppe, f.eks. ikke-etniske danskere. Derimod er det fortsat et problem, at Sprognævnet ikke har lyttet til en anden kritik i denne forbindelse, nemlig ønsket om også at få optaget passivformer i datid, i det mindste ved en række verber, hvor der kunne være tvivl. Det gælder blandt andet verber som misforstå og æde:

\footnotetext{
De fleste danskere ved, at man ligesom misforstås kan sige ædes i nutid passiv. Men er det tilladt? Og hvad med passivformen i datid? Hedder det misforstodes og ådes eller blev misforstået og blev cedt? Det får man ikke svar på i Danmarks officielle retskrivningsordbog. (Tarp 2002: 205).
}

Dette får man stadig ikke svar på i Retskrivningsordbogen anno 2012. Det kan helt klart betegnes som en mangel i en ordbog, hvis mission er at vejlede om korrekt retskrivning. Forklaringer gemt bort $i$ en generel grammatik kan ikke erstatte eksplicitte data i de enkelte artikler. Samme problemstilling gælder for princippet om, at bydemåde aldrig er anført i selve ordbogsdelen. Herom kan man i brugsvejledningen (s. 22) læse:

Imperativer som fx klistr, saml og åbn fremgår ikke under de enkelte opslagsord, men er omtalt nærmere i Retskrivningsreglerne $\S 30.2$.

Her tænker Retskrivningsordbogens forfattere ikke som leksikografer, hvis ypperste mission er så hurtigt og nemt som muligt at opfylde deres potentielle brugeres leksikografiske behov. Derimod ser de ud til at tænke som lingvister, der med et pædagogisk sigte ønsker at sende brugerne ud på et langt togt for at tilegne sig sprogets mysterier. Hver ting har sin berettigelse, men i en ordbog drejer det sig fremfor alt om at give hurtige og letfordøjelige svar. Anita Ågerup Jervelund (2013b), der har været projektleder på ordbogen, ignorerer i sin diskussion af imperativdannelse således helt den leksikografiske vinkel, dvs. brugerperspektivet.

Det er en kendsgerning, at selv folk med gode danskkundskaber ofte kommer i tvivl og har svært ved at danne imperativer som klistr, saml, åbn, hamr, krydr, pensl, sagtn, smuldr osv. Det samme gælder imperativform af oprindelige engelske ord som dope, fade, hike, outsource, pierce, shine, tape og tune, der alle er optaget i Retskrivningsordbogen og danner bydemåde efter andre regler end de oprindelige danske ord. På samme måde kan mange gode og sikre sprogbrugere være knap så gode og sikre, når de skal tage stilling til, om bydemåde af verber som kontrollere og notere skal skrives med eller uden accent: Hedder det kontroller eller kontrollér, noter eller notér? Dette får man end ikke svar på i Retskrivningsreglernes $\S 30.2$ om imperativ, men derimod i $\S 5.4$, der omhandler brugen af accenttegn. Det er i alle tilfælde en meget lang vej at gå, og det er på ingen måde brugervenligt. Det kan derfor anbefales, at Sprognævnet i en fremtidig femte udgave af Retskrivningsordbogen medtager i det mindste de imperativformer, der som ovennævnte kan volde problemer for en stor del af den potentielle brugergruppe. 


\section{Uløste problemer}

Som et eksempel på en inkonsekvent artikelstruktur i Retskrivningsordbogen pegede Tarp (2002: 206) også på den lidt besynderlige kendsgerning, at en række opslagsord var ledsaget af "en hel sværm af nyttige kollokationer, mens andre overhovedet ingen har" (punkt 10):

eksklusive prcep. (ikke medregnet) (fork.: ekskl.); prisen er eksklusive moms; alle kommer, børnene eksklusive.

så $a d v$., konj.; skynd dig, så (at) du når færgen; så gerne; så godt som; så lidt; så længe; så mange; så meget; så nær; så ofte; så sandt; så snart; så tit; så vel (gid det var så vel, men så vel som el. såvel som); så vidt jeg ved; for så vidt; så vist; og så videre (fork.: osv.).

virre $v b$., -ede; virre med hovedet.

virkelig $a d v$,; han har virkelig gjort sig umage; har han virkelig gjort sig umage?

visere $v b$., -ede (sigte, måle; påtegne); visere et pas.

vordende $u b ø j$. $a d j$.; en vordende far.

vrang (el. vrange) $s b$., -en; ret og vrang; vende vrangen ud.

Eksempel 8. Syv artikler fra Retskrivningsordbogens 2001-udgave

Disse artikler er stadig ledsaget af kollokationer i 2012-udgaven (virkelig har fået to mere). Samtidig har hovedparten af opslagsordene stadig ingen kollokationer tilordnet. Selv om kollokationer utvivlsomt er uhyre nyttige ved skriftlig tekstproduktion, har de vel næppe direkte noget med retskrivning at gøre, da de enkelte ord kan findes retskrevet andre steder i ordbogen. Det virker under alle omstændigheder, som om de stadig er tilfældigt spredt ud over ordbogens titusinder af opslagsord. I en fremtidig femte udgave må Sprognævnet beslutte sig. Det drejer sig mestendels om et enten-eller. Uanset hvad det ender med, må der relevante leksikografiske argumenter på bordet.

\section{Ordidentificerende betydningsdata}

En anden kritik af Retskrivningsordbogens tredje udgave var den noget tilfældige brug af forklarende data. I nogle tilfælde er ordidentificerende betydningsdata uomgængelige for at aflæse informationer om den korrekte retskrivning, f.eks. til at adskille de forskellige bøjningsparadigmer for profil og rad:

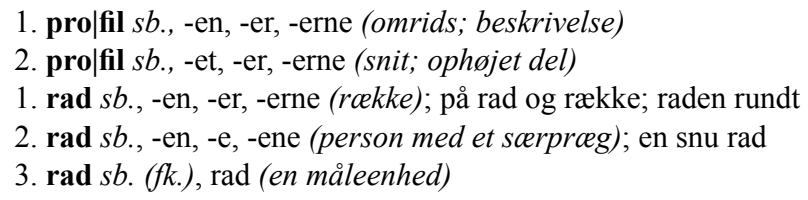

Eksempel 9. Fem artikler fra Retskrivningsordbogens 2012-udgave

I andre tilfælde er sådanne data ikke nødvendige for retskrivningen i snæver forstand, men ikke desto mindre "nyttige ved tekstproduktion, hvis brugeren ikke er helt sikker på, at han eller hun bruger det rigtige ord" (Tarp 2002: 207). Siden 2001 har Sprognævnet besluttet at øge antallet af opslagsord med forklarende data. Ifølge Jervelund (2013a) har 38 procent af opslagsordene nu sådanne data. I den forbindelse hedder det i Retskrivningsordbogens brugsvejledning (s. 13):

Der gives betydningsoplysninger ved opslagsord som skønnes at kunne give anledning til tvivl hos især de yngste af ordbogens brugere. Betydningsoplysningerne er i de fleste tilfælde ganske kortfattede idet de kun skal sikre en hurtig identifikation af opslagsordene. Ordbogens betydningsoplysninger skal derfor ikke betragtes som fuldstændige beskrivelser af de enkelte opslagsord betydning, og ordbogen kan ikke bruges som facitliste for ordenes betydning.

Med dette i mente ser det ud til, at Sprognævnet er gået ud over det opdrag, som det oprindelig har fået af Folketinget. Man kan mene, at det er en fornuftig beslutning i betragtning af nytteværdien for en del af den tilsigtede brugergruppe. Man må i den sammenhæng blot ikke glemme, at det stigende antal betydningsdata kan have den modsatte effekt blandt en anden del af bruger- 
gruppen, for hvem det er forstyrrende dataoverlæs. Det fremgår, at Sprognævnet også har gjort sig lignende tanker:

\begin{abstract}
Der er altså $62 \%$ af ordene der ikke har disse oplysninger, og der vil uden tvivl være nogle brugere af ordbogen der indimellem mangler en betydningsoplysning ved et opslagsord - ligesom der også indimellem vil være brugere der finder det overflødigt at en sådan oplysning er angivet. Det er nu engang vanskeligt at vurdere hvad der hører med til de yngste brugeres ordforråd da grænserne for dette er flydende. Og man skal huske på at Retskrivningsordbogen trods alt ikke er en betydningsordbog men en retskrivningsordbog, og i en sådan ordbog er det overflødigt at have betydningsoplysninger ved det basale ordforråd som abe og ncese. (Jervelund 2013a: 7)
\end{abstract}

Vi står her over for et sandt dilemma, som ikke kan finde sin optimale løsning i en trykt ordbog, med mindre Sprognævnet igen vælger at "arbejde efter reglerne". Derimod kan det uhyre nemt løses i en online-version, hvor angivelse af betydningsdata for eksempel kan være default-funktionen, mens en interaktiv option samtidig giver brugerne mulighed for at fravælge disse data, i det omfang de ikke er nødvendige. Dette ville utvivlsomt være ønskeligt, men det kræver, at Sprognævnet dropper den ide, at den trykte og elektroniske udgave skal være identiske ikke kun i det lovbestemte indhold, men også i formen dette indhold serveres på.

For at udvikle en sådan løsning må man under alle omstændigheder fastlægge et kriterie, som kan hjælpe til at skelne mellem på den ene side de betydningsdata, der er absolut nødvendige for retskrivning (korrekt stavning og bøjning), og på den anden side de betydningsdata, der kan vaere nyttige for nogle brugere ved tekstproduktion. Et sådant kriterie er fastlagt og anvendt i Den Danske Grammatik- og Staveordbog, som udelukkende anfører betydningsdata ved grammatisk homonymi, dvs. når det samme lemmatiserede grafem optræder med mere end en ordklasse eller bøjning. Til gengæld er disse data så mere udførlige end i Retskrivningsordbogen. Eksempelvis har Den Danske Grammatik- og Staveordbog betydningsdata:

- ved de to forskellige bøjninger af substantivet profil (ligesom Retskrivningsordbogen),

- $\quad$ ved de tre forskellige bøjninger af substantivet $\mathrm{rad}$ samt forkortelsen $\mathrm{rad}$ (Retskrivningsordbogen har ved de tre substantiver, men har ikke lemmatiseret forkortelsen),

- ved de to forskellige bøjninger af substantivet bog (Retskrivningsordbogen har kun ved den ene af dem),

- ved de tre forskellige bøjninger af substantivet bank (Retskrivningsordbogen har kun ved to af dem),

- ved både substantivet og adjektivet terminal (Retskrivningsordbogen har kun ved adjektivet),

- ved både substantivet og verbet banke (Retskrivningsordbogen har kun ved substantivet)

- ved både substantivet og verbet bøje (Retskrivningsordbogen har ikke ved nogen af dem),

- osv., osv.

I alle andre tilfælde - dvs. når der ikke er tale om grammatisk homonymi - er der ikke anført betydningsdata. Det er en meget simpel regel, som er nem at håndtere med henblik på at sikre systematik og yde hjælp til brugerne. Den betyder, at sidstnævnte kun får betydningsdata op på skærmen i de tilfælde, hvor der er to eller flere grammatiske valgmuligheder. På den måde kan brugerne hurtigt få de informationer, som de har behov for i den konkrete konsultation. I en kommende udgave burde Retskrivningsordbogen lade sig inspirere af denne regel, så der som minimum anføres betydningsdata i de tilfælde, hvor der er flere valgmuligheder. 


\section{På kant med loven}

I ovenstående afsnit så vi, at Sprognævnet har et befriende afslappet forhold til lovens bogstav med hensyn til inkorporering af ikke strengt nødvendige betydningsdata. Det er dog ikke altid, at en sådan "civil ulydighed" er på sin plads. For eksempel kritiserede Tarp (2002), at Retskrivningsordbogen siden sin anden udgave (1986) har behandlet de to ord retlig og retslig, der har noget med henholdsvis loven og domstolene at gøre, som om de var stavevarianter af samme ord. Dette problem gentages i 2012-udgaven:

ret|lig (el. retslig) adj., -t, -e

rets|lig (el. retlig) adj., -t, -e

Eksempel 10. To artikler fra Retskrivningsordbogens 2012-udgave

Anita Ågerup Jervelund skriver følgende om Sprognævnets beføjelser:

Sprognævnet bestemmer hvordan den officielle stavemåde af ordene skal være, men vi har ikke bemyndigelse til at give officielle betydninger af ordene, og det er der heller ingen andre institutioner der har. Man kan altså ikke bruge RO 2011 som facitliste for et ords "korrekte" betydning. (Jervelund 2009: 12)

I tilfældet retlig og retslig har Sprognævnet ikke tilføjet misvisende betydningsdata, men ved at behandle de to ord som synonyme (hvad de absolut ikke er) har nævnet alligevel givet dem "officielle betydninger". Det er beklageligt, at Sprognævnet ikke har lyttet til kritikken i dette tilfælde. Den valgte løsning bidrager næppe til at forbedre danskernes retskrivning og fornemmelse for deres modersmål. Hos folk med sans for sprogets nuancer skærer Sprognævnets nuværende løsning lige så meget i ørene, som det ville gøre hos det store flertal, hvis man satte retlig lig rettelig.

\section{Deskription, præskription eller proskription}

Inden for sprogvidenskaben arbejder man sædvanligvis med to forskellige metoder, når man skal samle, bearbejde og præsentere sproglige data, som er indsamlet fra forskellige kilder. Disse metoder er deskription og prceskription. Den opgave, som Folketinget har stillet Dansk Sprognævn, er i sit væsen selvsagt en præskriptiv opgave, nemlig at foreskrive hvordan det danske sprog skal retskrives. Men samtidig har den et element af deskription i sig, eftersom bekendtgørelsen om Sprognævnets ordbogsarbejde lægger op til, at nævnet - ud over traditionsprincippet - også skal følge sprogbrugsprincippet, ifølge hvilket ord og ordformer i dansk "skal skrives i overensstemmelse med den praksis som følges i gode og sikre sprogbrugeres skriftlige sprogbrug".

Kombinationen af disse to grundprincipper fører blandt andet med sig, at der i Retskrivningsordbogen forekommer en lang række dobbeltformer med hensyn til stavning og bøjning. Det er som udgangspunkt et godt og demokratisk princip, der forhindrer, at alt for mange plumper i og forvandler sig til sprogsyndere, når de ikke bruger en bestemt stave- eller bøjningsform. Helt problemløst er dette princip dog ikke, når det skal føres ud i livet. Den tidligere formand for Dansk Sprognævn, Niels Davidsen-Nielsen, skriver i den anledning i Nyt fra Sprogncevnet:

\footnotetext{
Sprognævnet kritiseres af og til for at operere med for mange dobbeltformer. Denne kritik bunder sikkert i at når folk slår op i en retskrivningsordbog, er det typisk for at få afklaret en usikkerhed, og så kan det føles irriterende at få stukket to stavemåder - eller måske endda en vifte af stavemåder - ud som lige korrekte. Men i de tilfælde hvor der ikke kan anføres gode grunde til at foretrække én stavemåde for en anden, og hvor stillingen altså er regulært uafgjort, må ordbogsbrugerne lære at styre deres irritation og at leve med dobbeltformer. Sprognævnet, der skal arbejde på videnskabeligt grundlag, kan jo ikke slå plat og krone. (Davidsen-Nielsen 2009: 24)
}

Davidsen-Nielsen er personligt tilhænger af, at antallet af dobbeltformer "nedbringes betragteligt" med det sigte at gøre retskrivningen "enklere og lettere at håndtere". Spørgsmålet er, om en sådan nedbringelse ikke snarere vil få den virkning, at endnu flere danskere gøres til lovbrydere og "laver sprogfejl, hvis de ikke uafbrudt slår op i deres ordbog" (Bergenholtz 2013b). Dette er til 
syvende og sidst et sprogpolitisk spørgsmål, som ikke vil blive nærmere diskuteret her. Det skal blot konstateres, at dobbeltformer i den ene eller anden udstrækning ikke står for fald inden for den nærmeste fremtid. Derfor er det nødvendigt at finde en løsning, som rent faktisk kan hjælpe brugerne, når de står over for sådanne former, f.eks. ved fnise og resurse versus ressource:

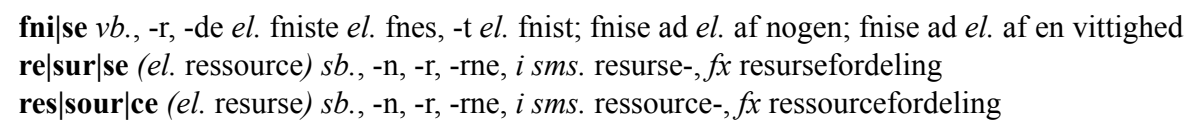

Eksempel 11. Tre artikler fra Retskrivningsordbogens 2012-udgave

Det er forståeligt, at brugere af Retskrivningsordbogen bliver perplekse, når de støder ind i artikler som ovenstående. Mange arbejder under stort tidspres og ønsker ikke at blive stillet i en situation, hvor de skal bruge tid og kræfter på at vælge mellem flere forslag, som de måske ikke har nogen forudsætninger for at tage stilling til. Som leksikograf kan man ikke som Davidsen-Nielsen sige til brugerne, at de skal "lære at styre deres irritation". Især fordi der faktisk findes alternativer. I punkt 3 i sin kritik af Retskrivningsordbogens tredje udgave foreslog Tarp (2002) derfor, at Sprognævnet fremover "for brugervenlighedens skyld" anvender den leksikografiske metode, som kaldes proskription. Denne metode går først og fremmest ud på at anbefale én form uden nødvendigvis at udelade eller forbyde andre former (se Bergenholtz 2001, 2003). Eksempler på, hvordan en ordbogsartikel, der er udarbejdet efter denne metode, eventuelt kunne se ud, kan findes i Den Danske Netordbog:

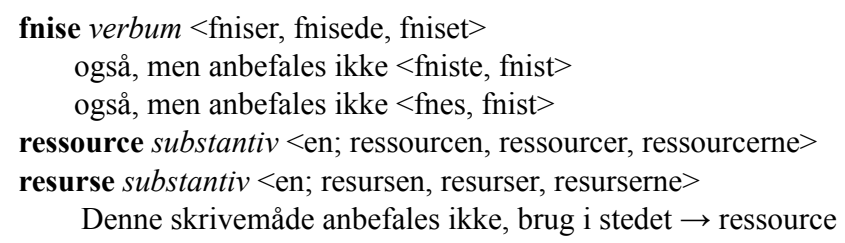

Eksempel 12. Uddrag af tre artikler fra Den Danske Netordbog

Som det fremgår, anfører Den Danske Netordbog nøjagtig de samme stave- og bøjningsformer som Retskrivningsordbogen, blot med den forskel, at den anbefaler bestemte former og dermed gør det lettere for brugerne at finde en hurtig løsning på deres problemer. Et andet og lignende problem i Retskrivningsordbogens 2001-udgave var spørgsmålet om, hvorvidt DNA og tilsvarende forkortelser skal skrives med store eller små bogstaver (punkt 7). Dengang fulgte Sprognævnet det generelle princip om, at forkortelser, der er gledet ind i almensproget, skal skrives med små bogstaver. Det bragte imidlertid nævnet på kant med "genteknologer og lignende fagfolk", som ville blive "helt til grin i deres faglige miljøer", hvis de skrev DNA med små bogstaver (Tarp 2002: 204).

Sprognævnet har lyttet til denne kritik, som er kommet fra især faglige miljøer, og har ændret den generelle regel, således at det i dag er officielt tilladt at skrive DNA og lignende initialforkortelser, der er appellativer, med både små og store bogstaver. Informationsmedarbejder i Dansk Sprognævn, Jørgen Nørby Jensen, skriver herom i Nyt fra Sprogncevnet:

\footnotetext{
Et særligt problem var der med de forkortelser som anvendes af fagfolk, men som også har en vis udbredelse i almensproget. Forkortelsen dna må siges at tilhøre almensproget. Den har stået i Retskrivningsordbogen siden 1996 og findes desuden i almensproglige ordbøger som Nudansk Ordbog og Den Danske Ordbog. I fagsproget optræder den imidlertid ofte sammen med forkortelsen $R N A$, der ikke er lige så kendt, og som kun kan slås op i fremmedordbøgerne. Hvis man skulle følge den officielle retskrivning, ville man altså være nødt til at skrive $R N A$ (med store bogstaver), men dna (med små), og det var naturligvis ikke hensigtsmæssigt. (Jensen 2013: 27)
}

Forklaringen om sammenkoblingen med $R N A$ og opslag i fremmedordbøger (hvorfor ikke fagordbøger?) virker lidt kringlet, og det endelige resultat, som det er udmøntet i Retskrivningsordbogen anno 2012, er da heller ikke optimalt: 
DNA (el. dna) $s b$., DNA'en $e l$. DNA'et, $i$ sms. DNA-, $f x$ DNA-molekyle, DNA-sekventering

dna (el. DNA) $s b$., dna'en $e l$. dna'et, $i$ sms. dna-, $f x$ dna-molekyle, dna-sekventering

Eksempel 13. To artikler fra Retskrivningsordbogens 2012-udgave

Her bliver de brugere, der konsulterer ordbogen for at få hjælp til skriftlig tekstproduktion, igen stillet i en svær valgsituation, både hvad angår stavemåde (med små eller store bogstaver?) og bøjningsparadigme (DNA'et eller DNA'en?). Hvad ville der være til hinder for, at Sprognævnet gik ind og anbefalede bestemte former - eller i det mindste oplyste om, at i faglige sammenhænge bør man skrive DNA med store bogstaver? I Den Danske Netordbog har forfatterne valgt følgende løsning, som dog udfordrer Sprognævnets grundprincip om små bogstaver i dansk retskrivning.

DNA forkortelse <et; DNA'et, DNA'er, DNA'erne> også, men anbefales ikke <en; DNA'en, DNA'er, DNA'erne>

dna forkortelse <et; dna'et, dna'er, dna'erne>

også, men anbefales ikke <en; dna'en, dna'er, dna'erne >

Denne skrivemåde anbefales ikke, brug i stedet $\rightarrow$ DNA

Eksempel 14. Uddrag af to artikler fra Den Danske Netordbog

Uanset hvilken løsning man konkret foretrækker i dette tilfælde, er det svært at forstå, at Sprognævnet ikke for længst har besluttet at anvende proskription i sit leksikografiske arbejde med Retskrivningsordbogen. En sådan metode er på ingen måde i modstrid med Sprognævnets lovgrundlag, da det stadig vil være nævnet, der fastlægger de officielt tilladte stave- og bøjningsformer med udgangspunkt $i$ traditions- og sprogbrugsprincippet, men med den vigtige nuance, at én af disse former nu anbefales for at undgå "irritation" hos brugerne. Måske ligger forklaringen på nævnets tøven i de betydningsdata, som det selv anfører til ordene proskribere og proskription:

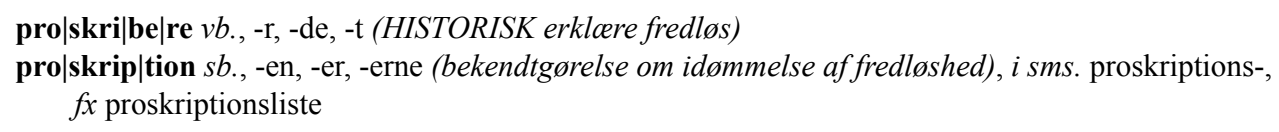

Eksempel 15. To artikler fra Retskrivningsordbogens 2012-udgave

I leksikografisk forstand har proskription ikke noget at gøre med at erklcere ordene fredløse, men tværtimod at anbefale dem til gavn for brugerne af det leksikografiske produkt. Dertil kommer, at proskription i moderne dansk hovedsagelig bruges inden for leksikografien, dvs. med betydningen anbefaling. Dansk Sprognævn kunne derfor med fordel "modernisere" ovenstående betydningsdata.

\section{Stavefejl og forsvundne dobbeltformer}

I punkt 6 i kritikken af forrige udgave af Retskrivningsordbogen hedder det:

Retskrivningsordbogen indeholder kun de tilladte og officielle stavemåder. Det ville imidlertid være til stor hjælp for brugerne, hvis typiske fejl eller forældede stavemåder, som netop er gledet ud, også blev anført i ordbogen med henvisning til de gældende staveformer. Det ville hjælpe dårlige stavere til at finde den rigtige stavemåde. (Tarp 2002: 203-204)

Man kunne her tilføje, at det ikke kun ville hjælpe dårlige stavere, men også andre brugere, som bliver taget med bukserne nede, når Sprognævnet pludselig gennemfører ændringer i omkring tre procent af alle opslagsord. Det kan konstateres, at nævnet har siddet denne kritik overhørig. Hverken i den trykte eller elektroniske udgave er det muligt at tilgå artiklerne via stavefejl eller forældede stave- og bøjningsmåder. Lad os tage tre ord, hvor Sprognævnet har ændret henholdsvis stavning og bøjningsformer siden sidste udgave: majonoese, aften og køkken. 
I anden udgave af Retskrivningsordbogen (1986) gennemførte Sprognævnet en række ændringer af retskrivningen, der allerede inden udgivelsen førte til en heftig polemik, der er gået over i historien som majoncesekrigen. En af de omstridte ændringer var netop, at Sprognævnet ønskede at fordanske det oprindeligt franske mayonnaise til majoncese. Andre og lidt mere upåagtede ændringer var ændring af bøjningsmønsteret for ord som aften og køkken, hvor henholdsvis den bestemte entalsform aftnen og formerne køknet, køkner og køknerne blev tilladt som alternative bøjningsformer.

Disse forandringer slog aldrig rigtigt igennem, og i 2012-udgaven af Retskrivningsordbogen valgte Sprognævnet derfor at opgive dobbeltformerne for disse tre ord og gå tilbage til de staveog bøjningsformer, som var gældende 57 år tidligere, da ordbogen helt tilbage i 1955 udkom i sin første udgave. Problemet er imidlertid, at disse - og andre tilsvarende - former trods den ringe succes opnåede en vis, omend beskeden brug og derfor kan findes i eksisterende tekster. Der kan som følge heraf være brugere af ordbogen, som kan komme i tvivl om, hvorvidt disse stave- og bøjningsformer er rigtige, når de i deres egenskab af skribenter, korrekturlæsere, sprogrevisorer, opgavebedømmere osv. støder på dem i forskellige tekster.

Hvis man eksempelvis søger på majoncese i netudgaven, får man som svar Ingen resultater. Det kan en bruger så tolke på to måder: 1) at ordet godt nok er rigtigt stavet men er gledet ud af ordbogen sammen med andre ord siden forrige udgave, eller 2) at denne stavemåde ikke længere er tilladt. Men uanset hvad vil tvivlen nage, indtil man på den ene eller anden måde får vished, for eksempel ved at søge på mayonnaise, hvis man ellers ved, hvordan dette frankofile ord staves.

Et fremskridt i online-versionen af den nye Retskrivningsordbog er, at det nu er muligt at søge direkte på (tilladte) bøjningsformer af opslagsordene. Men søger man på de nu ikke længere tilladte former aftnen, køknet, køkner og køknerne, får man ligesom ved majoncese et Ingen resultater smidt i hovedet. Dette er mildest talt ikke ret brugervenligt. Det skal ses i relief af to andre danske netordbøger, som har valgt at takle problemet på noget mere konstruktiv vis. I Den Danske Netordbog kan brugerne således via søgefunktionen få direkte adgang til opslagsordet majoncese, hvor de så bliver oplyst om, at Dansk Sprognævn ikke længere godtager denne skrivemåde. Og tilsvarende oplysninger fås i forbindelse med opslagsordene aften og køkken:

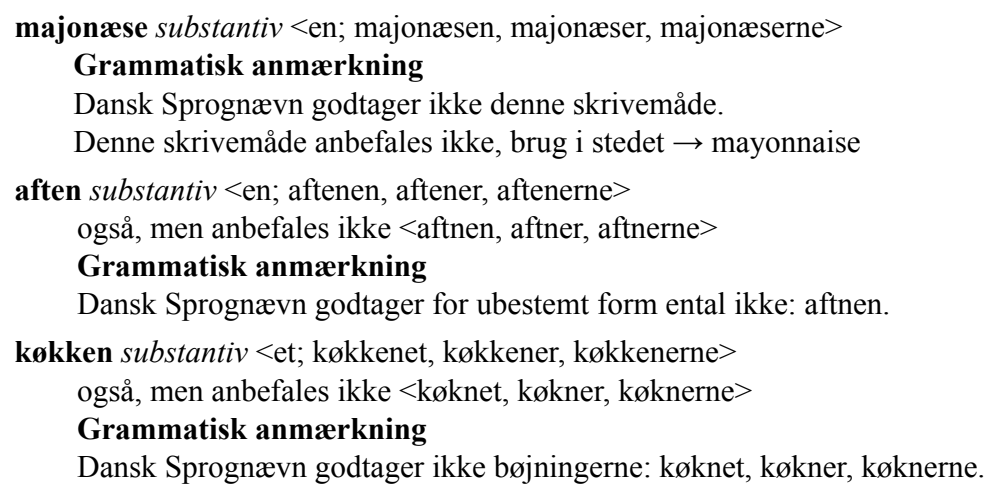

Eksempel 16. Uddrag af tre artikler fra Den Danske Netordbog

Ved søgning på majonæse i Den Danske Ordbogs online-udgave bliver brugerne ledt direkte til opslagsordet mayonnaise, hvor de får at vide, at stavemåden majoncese ikke længere er officiel. Og tilsvarende oplysninger får man om de ovenfor nævnte bøjningsformer af aften og køkken:

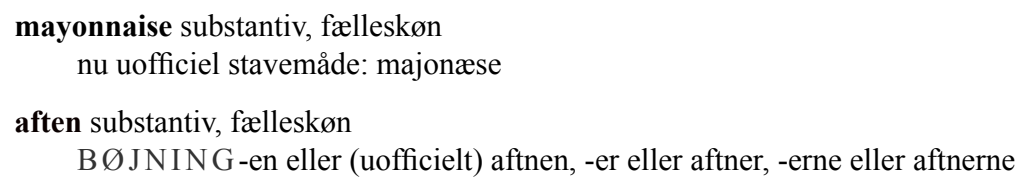


køkken substantiv, intetkøn

B ØJNING -et eller (uofficielt) køknet, -er eller (uofficielt) køkner, -erne eller (uofficielt)

køknerne

Eksempel 17. Uddrag af tre artikler fra Den Danske Ordbog

Selv om artikelstrukturen i Den Danske Ordbog er knap som overskuelig som i Den Danske Netordbog, hvor den proskriptive metode er kommet til fuld udfoldelse, er løsningerne i begge ordbøger udtryk for en langt mere realistisk måde at omgås ændringer i retskrivningen på. Herved får man også løst problemet med ord, som alt for hurtigt kommer og går i Retskrivningsordbogen (punkt 4). Det var Dansk Sprognævn, som i sin tid trods store protester indførte former som $m a$ joncese, aftnen, køknet, køkner og køknerne. Nu har nævnet efter 26 år ikke uforståeligt besluttet at kaste håndklædet i ringen. Men det kan undre, at Dansk Sprognævn nu lader, som om problemet aldrig har eksisteret. Det virker som et klassisk eksempel på en kaptajn, der som den første forlader skuden.

\section{Andre tilgangsproblemer}

En af nyskabelserne i den nye udgave af Retskrivningsordbogen er, at der ved en del opslagsord er anført, i hvilken form de indgår i sammensætninger. Der er her som udgangspunkt tale om en klar forbedring, idet det oplyses, om disse ord er uændrede (1), får tilføjet bindbogstaver (2), bliver afkortet (3), har dobbeltformer (4), har mere end én form (5) eller udviser afvigelser (6 og 7), når de optræder som første led i en sammensætning:

1. fa|san $s b$., -en, -er, -erne, $i$ sms. fasan-, $f x$ fasanjagt

2. hegn $s b$., -et, hegn, -ene, $i$ sms. hegns-, $f x$ hegnstråd

3. ro|te|re $v b$., -r, -de, -t, $i$ sms. roter-, $f x$ roterovn

4. trus $\mid \mathbf{s e l} s b$., truslen, trusler, truslerne, $i$ sms. trussel- $e l$. trussels-, $f x$ trussel(s)billede, trussel(s)brev

5. $\quad$ kro|ne $s b .$, -n, -r, -rne, $i$ sms. kron-, $f x$ kronjuvel, og krone-, $f x$ kronebeløb

6. ren|te $s b$., -n, -r, -rne, $i$ sms. rente-, $f x$ renteafkast, $d o g$ rentes- $i$ rentesregning

7. be|drift $s b$., -en, -er, -erne (prcestation; virksomhed), $i$ sms. bedrifts-, $f x$ bedriftslæge, bedriftsråd, $d o g$ bedrift- $e l$. bedrifts- $i$ bedrift(s)værn

Eksempel 18. Syv artikler fra Retskrivningsordbogens 2012-udgave

Oplysninger af denne slags er yderst relevante for et sprog som dansk, der er kendetegnet ved mange komposita, hvor netop sammenkædningen ofte volder problemer selv for garvede sprogbrugere. Dog må man sige, at det er voveligt at indføre en forkortelse som sms. for sammensœetning. Mange, især yngre brugere, vil givetvis blive forvirret og forveksle den med de små beskeder, som de dagligt sender fra deres mobiltelefoner. Forkortelsen sams. ville i den forbindelse have været et bedre valg, da den samtidig er mere gennemskuelig. Men ser man bort fra dette forholdsvis lille problem, er der imidlertid opstået et noget større problem, som på udmærket vis illustreres af opslagsordet strand og de forskellige sammensætninger, hvori dette ord indgår som første led:

strand $s b .$, -en, -e, -ene, $i$ sms. strand-, $f x$ strandplante, strandstol

strand|bred $s b$., -den, -der, -derne

strand|eng $s b$., -en, -e, -ene, $i$ sms. strandengs-, $f x$ strandengsområde

strand|fod|ring sb., -en, -er, -erne (tilførsel af sand til kyster som nedbrydes af bølgerne)

strand|fo|ged $s b$., -en, -er, -erne

strand|hugst $s b$., -en, -er, -erne; gå på strandhugst

stran|ding $s b$., -en, -er, -erne, $i$ sms. strandings-, $f x$ strandingsgods

strand|jagt $s b$., -en, -er, -erne, $i$ sms. strandjagt-, $f x$ strandjagtforening

strand|jæ|ger $s b$., -en, -e, -ne

strand/kant $s b$, , -en, -er, -erne 


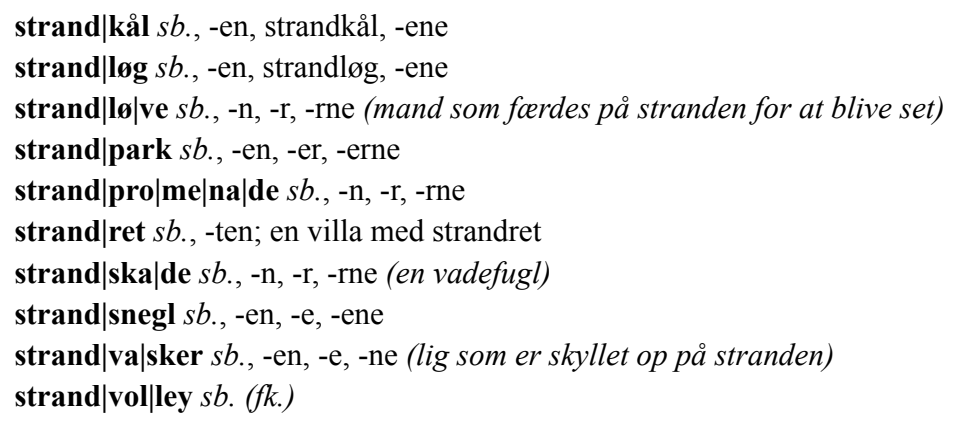

Eksempel 19. Artikler fra Retskrivningsordbogens 2012-udgave

Hvis nogle brugere i den trykte ordbog ønsker at få nogle oplysninger om strandplante eller strandstol, hvad gør de så? Først leder de givetvis i selve ordlisten - uden resultat! Dernæst kan enkelte af disse brugere måske få det indfald, at de kan søge under strand. I dette tilfælde er de heldige, men det minder en lille smule om lørdagslotto og er under alle omstændigheder unødigt besværligt. En meget nemmere og brugervenlig løsning ville være også at optage strandplante og strandstol som selvstændige lemmata, selv om dette røver plads.

I online-udgaven, hvor pladsen ikke er et problem, kunne man derimod forvente, at de to ord figurerede som opslagsord. Men nej! Princippet om, at de to udgaver skal være identiske i form og indhold, forhindrer dette. Alternativt kunne man så forvente, at man ligesom ved bøjningsformer kunne søge direkte på strandplante og strandstol og derigennem blive sendt videre til opslagsordet strand, hvor de er at finde. Heller ikke dette er muligt - og det er bare ærgerligt!

\section{Antallet af opslagsord}

Det første punkt i kritikken af forrige udgave af Retskrivningsordbogen gik på antallet af opslagsord:

Retskrivningsordbogen har for få opslagsord. Sammenligner man med tilsvarende svenske eller tyske retskrivningsordbøger, indeholder Dansk Sprognævns ordbog kun omtrent halvt så mange opslagsord. Det er for dårligt efter så mange år. Det drejer sig først og fremmest om de mest almindelige simpleksord, dvs. ikke-sammensatte ord. Men ser man på den forholdsvis store kerne af mennesker, som i kraft af deres arbejde næsten dagligt har brug for en ordbog, er det for det meste ikke netop disse ord, som volder dem størst problemer, men de ord, som ligger uden for denne kreds, det være sig komposita eller faglige simpleksord. (Tarp 2002: 202)

I sin 2001-udgave havde Retskrivningsordbogen i alt ca. 64.000 opslagsord, og efter at have slettet, tilføjet og flyttet er 2012-udgaven endt på - ca. 64.000 ord i alt! Det dækker dog over ca. 10.000 andre ord, som ikke er egentlige opslagsord, men såkaldte sammensætningseksempler (såsom strandplante og strandstol). I Nyt for Sprogncevnet bringer projektleder Anita Ågerup Jervelund (2013: 6) følgende sammenligning mellem antallet af ord i de to udgaver:

\begin{tabular}{|l|l|}
\hline RO 2001 & RO 2012 \\
\hline ca. 64.000 opslagsord & ca. 64.000 opslagsord \\
\hline $\begin{array}{l}\text { ca. } 4000 \text { sammensæt- } \\
\text { ningseksempler }\end{array}$ & $\begin{array}{l}\text { ca. } 10.000 \text { sammensæt- } \\
\text { ningseksempler }\end{array}$ \\
\hline $\begin{array}{l}\text { ca. } 15 \text { slettede opslags- } \\
\text { ord (ift. R0 1996) }\end{array}$ & $\begin{array}{l}\text { ca. } 4.500 \text { slettede op- } \\
\text { slagsord (ift. R0 2001, } \\
\text { mange er blevet sam- } \\
\text { mensætningseksem- } \\
\text { pler) }\end{array}$ \\
\hline $\begin{array}{l}\text { ca. } 1000 \text { nye opslagsord } \\
\text { (ift. R0 1996) }\end{array}$ & $\begin{array}{l}\text { ca. 4.500 nye opslags- } \\
\text { ord (ift. R0 2001) }\end{array}$ \\
\hline ca. 68.000 ord i alt & ca. 74.000 ord i alt \\
\hline
\end{tabular}

Eksempel 20. Oversigt over antal ord i 2001- og 2012-udgaven 
Det er mildest talt ikke en imponerende kvantitativ fremgang, som Retskrivningsordbogen kan udvise langt inde i den digitale tidsalder. Det er i det hele taget besynderligt, at nogle ord er slettet eller degraderet til "sammensætningseksempler". At et ord er "sjældent", er ikke noget argument for at slette det i en ordbog, hvis opgave er at yde hjælp til retskrivning - også (eller måske netop) af de ord, der ikke så hyppigt bruges.

Dansk Sprognævn har af Folketinget fået til opgave at fastlægge retskrivningen for det danske sprog. Denne opgave bliver kun delvist løst, nærmere bestemt for de ca. 64.000 ord, der er medtaget som opslagsord i Retskrivningsordbogen. Uden for denne ordbog, hvor der findes et mindst lige så stort antal ord (både simpleksord og komposita), råder der Klondyke-lignende tilstande med hensyn til retskrivning. På samme måde som forskerne lidt efter lidt kortlagde det menneskelige genom, burde Dansk Sprognævn stille sig den opgave at kortlægge hele det danske sprog og fastlægge retskrivningen for alle ord, ikke blot de 64.000 opslagsord, som nu er optaget i Retskrivningsordbogen. Det aktive danske ordforråd er langt større end disse relativt få ord. Uanset om ordene er hyppige eller sjældne, har folk krav på hjælp, når de nu engang ønsker at bruge dem og nedfælde dem på skrift.

Man får uundgåeligt den mistanke, at 64.000 er et slags magisk tal for Sprognævnet, ligesom $60 \mathrm{er}$ det inden for sort humor og komik. Som tidligere nævnt er der fysiske grænser for, hvor mange data en håndterbar trykt ordbog kan rumme, hvis de ikke skal presses sammen og gøres ulæselige for en stor del af den tilsigtede brugergruppe. Men dette hensyn eksisterer ikke i den digitale verden.

\section{Trykt og elektronisk udgave}

Ovenfor er det flere gange blevet rejst som et problem, at Retskrivningsordbogens trykte og elektroniske udgaver er identiske ikke alene med hensyn til antal opslagsord, men også hvad angår de enkelte artiklers indhold og form. På den måde hører netudgaven til den type online-ordbøger, der går under betegnelsen hurtige heste (se Tarp 2011: 59). Disse ordbøger kendetegnes ved, at de enkelte artikler er statiske og bygget op efter samme læst som i trykte ordbøger. Eneste virkelige nyskabelse er muligheden for hurtigere søge- og tilgangsveje.

Det er uforståeligt, at Dansk Sprognævn ikke i højere grad har udnyttet de muligheder, som den nye teknologi og teknik åbner op for. I Nyt fra Sprogncevnet diskuterer nævnets direktør, Sabine Kirchmeier-Andersen, denne problemstilling. Hun starter med at konstatere, at "tiden er ved at løbe fra de trykte ordbøger, og kravene om at publicere digitalt er kommet for at blive" (Kirchmeier-Andersen 2013: 36). Sidste del af denne konstatering er ubestridelig, men der er derimod intet, der klart indikerer, at de trykte ordbøger vil være passé inden for den nærmeste fremtid, selv om deres indflydelse selvsagt bliver relativt mindre. Sprognævnets direktør gør det da også klart, at nævnet endnu ikke er parat til at droppe den trykte ordbog. Derfor må man forudse, at der gennem et længere forløb fortsat vil eksistere en trykt version af Retskrivningsordbogen side om side med elektroniske versioner på forskellige medier og applikationer.

Kirchmeier-Andersen diskuterer derefter muligheden for "at tilføje nye ord og lave andre ændringer" i online-ordbogen, noget som allerede sker med nævnets online-ordbog Nye ord $i$ dansk. Hun råder ikke uden grund til at "udvise stor forsigtighed" i denne sammenhæng:

\footnotetext{
Mens alle ordbogsbrugere formentlig ville opfatte det som en udstrakt service at nævnet løbende tilføjede nye ord til ordbogen og tilføjede flere nyttige oplysninger om ordene, ville de samme brugere næppe bryde sig om at der løbende blev lavet ændringer i etablerede ords stavemåde eller ligefrem principielle ændringer i retskrivningsreglerne. Man ville kunne risikere at man den ene dag var i god overensstemmelse med den officielle norm, og den næste dag ganske uforvarende ville være lovbryder. Derfor skal alle opdateringer overvåges nøje, og der skal holdes øje med om der blandt de planlagte løbende tilføjelser og ændringer kan være principielle ændringer. ” (Kirchmeier-Andersen 2013: 37)
}

Det er så sandt, som det er sagt! Men Sprognævnets direktør synes ikke desto mindre at være for tilbageholdende, hvad angår nye ord og ændringer. Hun argumenterer i denne sammenhæng, at 
principielle ændringer skal gennem "hele den lovregulerende godkendelsesproces". Det er også rigtigt. Men spørgsmålet er, hvor mange af de mulige kandidater til optagelse i ordbogen der er berørt af denne problemstilling. Det er ganske givet et lille mindretal. Endelig fremfører Kirchmeier-Andersen også det argument, at "den stigende anvendelse af ordbogen i digitale applikationer" betyder, at den løbende tilføjelse af nye ord til ordbogen heller ikke er helt uproblematisk:

\begin{abstract}
Hver gang ordbogen opdateres, vil de eksisterende ordlister rundt omkring blive forældet. Det har hidtil ikke været noget problem da den trykte ordbog og den digitale ordbog har været nøjagtigt identiske. Det vil de ikke være i fremtiden, og der skal derfor findes gode og sikre digitale metoder til at holde de mange brugere af Sprognævnets ordlister ajour og at opdatere den trykte ordbog i passende intervaller. Et tilbagevendende spørgsmål har i denne sammenhæng været om der fortsat skal tages ord ud af ordbogen. Hvor pladsen i den trykte ordbog har lagt en naturlig begrænsning for de ord der kunne være med, er der i den digitale verden i praksis ingen fysiske grænser for ordbogens størrelse. Det er derfor fristende at lade ordbogen vokse, men det vil formentlig samtidig betyde et farvel til den trykte bog i den form vi kender den i dag. En så vidtrækkende beslutning er nævnet imidlertid ikke parat til at tage så længe interessen for at besidde en "rigtig" bog er til stede. (Kirchmeier-Andersen 2013: 38)
\end{abstract}

Problemet med at "holde de mange brugere af Sprognævnets ordlister ajour" kan man helt sikkert finde en løsning på, uden at det gøres til en bremseklods for Retskrivningsordbogens udvikling. Det lyder fornuftigt, at opdateringen af den trykte ordbog skal ske med "passende intervaller", såfremt disse intervaller er lange nok. Kirchmeier-Andersens løfterige vision om, at den trykte og digitale ordbog ikke i fremtiden vil være identiske, ser derimod ud til at konflikte med hendes afsluttende bemærkning om, at en voksende ordbog vil "betyde et farvel til den trykte bog i den form vi kender den i dag". Hvorfor egentlig det?

Hvis den trykte og elektroniske ordbog ikke længere behøver at være identiske, hvad er der så til hinder for, at der optages et stadig stigende antal ord i den digitale udgave, uden at det samme sker i den trykte udgave, som har sine klare begrænsninger i denne henseende? Så længe der ikke er konflikt mellem stavning og bøjning af de ord, som går igen i begge udgaver, er der ingen teoretiske eller praktiske - og sikkert heller ikke lovgivningsmæssige - hindringer for at tage et skridt, som på alle mulige måder er brugervenligt. I samme håndevending kunne man afskaffe de irriterende metaleksikografiske forkortelser og skrive dem ud i deres fulde form i den elektroniske udgave. Det samme kunne man gøre med alle bøjningsformer, hvad der ville gøre livet nemmere for den urutinerede bruger af leksikografiske produkter. Og endelig kunne man give brugerne forskellige interaktive optioner for at tilpasse ordbogen til deres præcise behov, for eksempel muligheden for at fravælge overflødige betydningsdata som diskuteret ovenfor, og således tage skridt til at forvandle den fra en hurtig hest til en leksikografisk Ford T Model med dynamiske data og funktionstilpassede artikler (se Tarp 2011: 60).

Mulighederne er mange, hvis man blot gør op med indgroede vaner og business-as-usual-tænkning. Skrædderen, der blev ved sin læst, mistede som bekendt sit job.

\title{
14. Konklusion
}

Overskriften i denne artikel hedder "Retskrivningsordbog mellem to stole". Disse to stole er henholdsvis den sprogpolitiske og den leksikografiske. Artiklen har koncentreret sig om sidstnævnte, velvidende at begge stole er nødvendige for at få et godt slutprodukt. Den har med flere eksempler vist, at Dansk Sprognævn i mange henseender ikke er klædt leksikografisk godt nok på til at skabe et kvalitetsprodukt. Da forrige udgave af Retskrivningsordbogen udkom tilbage i 2001, forsøgte medarbejdere ved Center for Leksikografi i Århus at indlede en konstruktiv dialog med ordbogens forfattere. Det blev taget ilde op, og Centrets daværende leder, professor Henning Bergenholtz, blev tilsyneladende erklæret persona non grata i Sprognævnet. Nu er den gal igen. Det er alle danskskrivendes håb og ønske at få en retskrivningsordbog, der er så god og brugervenlig som overhovedet muligt. Der findes leksikografisk ekspertise i Danmark, og det ville være dumt ikke at bruge den. 
En konstruktiv dialog indbefatter velargumenteret og fremadrettet kritik. En offentlig institution som Dansk Sprognævn bør ikke være ømskindet i denne henseende. Som vogter af det danske sprog og udgiver af en officiel retskrivningsordbog befinder nævnet sig nærmest per definition på øretævernes holdeplads. Det kan forekomme uretfærdigt, men der er ikke så meget at gøre ved det. Fremskridt er i høj grad et produkt af en sund konfrontation mellem ideer.

Som afslutning på disse alvorsord er det nødvendigt at give Sprognævnet noget velfortjent ros. Den trykte udgave af den nye Retskrivningsordbog er forholdsvis billig og online-udgaven helt gratis. Dette er efterhånden en sjældenhed i vores overprivatiserede og profitbetonede samfund. Denne service til borgerne skal Dansk Sprognævn have stor ros for og lige så stor støtte til at fastholde!

\section{Litteratur}

\section{Ordboger}

Den Danske Grammatik- og Staveordbog 2013: Udarbejdet af Henning Bergenholtz i samarbejde med Heidi Agerbo Pedersen under medvirken af Andreas Bodilsen, Sofie Weiss Dohrn, Kathrine Brosbøl Eriksen, Helene R. Gudmann, Helene Halkjær Jensen, Jesper Halkjær Jensen, Christian Kjølhede, Jane Nguyen. Database: Richard Almind, Rasmus Theodor Styrk og Jesper Nielsen. Odense: Ordbogen.com [online]. www.ordbogen.com (april 2013).

Den Danske Netordbog 2013. Udarbejdet af Henning Bergenholtz i samarbejde med Heidi Agerbo Pedersen under medvirken af Filip Bodilsen, Kathrine Brosbøl Eriksen, Helene R. Gudmann, Stine Busk Hedegaard, Helene H. Jensen, Jesper Halkjær Jensen, Christian Kjølhede og Thuy Jane Dinh Nguyen. Odense: Ordbogen A/S [online]. www.ordbogen.com (april 2013).

Den Danske Ordbog 2013: København: Det Danske Sprog- og Litteraturselskab [online]. http://ordnet.dk/ddo (april 2013).

Retskrivningsordbog. 1. udgave 1955: København: Dansk Sprognævn, i kommission hos Gyldendal.

Retskrivningsordbogen. 2. udgave 1996: Udgivet af Dansk Sprognævn. København: Aschehoug.

Retskrivningsordbogen. 3. udgave 2001: Udgivet af Dansk Sprognævn. København: Alinea-Aschehoug.

Retskrivningsordbogen. 4. udgave 2012: Udgivet af Dansk Sprognævn. København: Alinea A/S [online]. http://www. dsn.dk/ro/ro.htm (april 2013).

\section{Anden litteratur}

Bergenholtz, Henning 2001: Proskription, oder: So kann man dem Wörterbuchbenutzer bei Textproduktionsschwierigkeiten am ehesten helfen. I: A. Lehr et al. (Eds.): Sprache im Alltag. Berlin, New York: De Gruyter, 499-520.

Bergenholtz, Henning 2003: User-oriented Understanding of Descriptive, Proscriptive and Prescriptive Lexicography. Lexikos 13, 65-80.

Bergenholtz, Henning 2012a: En retskrivningsordbog, hvor der er for lidt om retskrivning. Den Korte Avis, 1. november 2012.

Bergenholtz, Henning 2012b: Hedder det gymnasium eller gymnasie? Ja, hvad synes du selv? Den Korte Avis, 8. november 2012.

Bergenholtz, Henning 2012c: En indviklet måde at forenkle på. Den Korte Avis, 15. november 2012.

Bergenholtz, Henning 2012d: Man pønser på at forbyde husmoderporno. Den Korte Avis, 22. november 2012.

Bergenholtz, Henning 2012e: "Fuck" og "fucking" er med i ordbogen, men en masse nødvendige ord mangler. Den Korte Avis, 29. november 2012.

Bergenholtz, Henning 2012f: Anbefaler du en bestemt sprogbrug? Sådan en Stasi-agent! Den Korte Avis, 3. december 2012.

Bergenholtz, Henning 2012g: Dansk Sprognævn har ingen klar sprogpolitik. Den Korte Avis, 17. december 2012.

Bergenholtz, Henning 2013a: Tåbelige regler skaber unødig forvirring. Den Korte Avis, 4. marts 2013.

Bergenholtz, Henning 2013b: Et sprogligt Forbudsdanmark. Den Korte Avis, 12. marts 2013.

Bergenholtz, Henning og Rufus H. Gouws 2006: How to Do Policy with Dictionaries. Lexikos 16, 13-45.

Dansk Sprognævn 2013: Nyt fra Sprogncevnet 1, marts 2013.

Davidsen-Nielsen, Niels 2009: Dobbeltformer til afstemning. Nyt fra Sprogncevnet 4, december 2009, 24-27. 
Gouws, Rufus H. og Sven Tarp 2008: A lexicographic approach to language policy and recommendations for future dictionaries. Lexikos 18, 232-255.

Jensen, Jørgen Nørby 2013: Store og små bogstaver i initialforkortelser. Nyt fra Sprogncevnet 1, marts 2013, $26-27$.

Jervelund, Anita Ågerup 2009: En ny og bedre Retskrivningsordbog. Nyt fra Sprogncevnet 4, december 2009, 12-14.

Jervelund, Anita Ågerup 2013a: En ny og bedre Retskrivningsordbog - det endelige resultat. Nyt fra Sprogncevnet 1, marts 2013, 5-7.

Jervelund, Anita Ågerup 2013b: Mindre ændringer i retskrivningsreglerne. Nyt fra Sprogncevnet 1, marts 2013, 30-35.

Kirchmeier-Andersen, Sabine 2013: Retskrivningsordbogen i fremtiden - analog eller digital? Nyt fra Sprogncevnet 1, marts 2013, 36-39.

Tarp, Sven 2002: Kritiske bemærkninger til den officielle danske retskrivningsordbog. LexicoNordica 9, 195-208.

Tarp, Sven 2008: Lexicography in the borderland between knowledge and non-knowledge. Tübingen: Niemeyer.

Tarp, Sven 2011: Lexicographical and Other e-Tools for Consultation Purposes: Towards the Individualization of Needs Satisfaction. I: Pedro A. Fuertes-Olivera and Henning Bergenholtz (Eds.): e-Lexicography: The Internet, Digital Initiatives and Lexicography. London, New York: Continuum, 54-70. 